\title{
Comparison of collagen profile and tenderness of muscles from heifers and single-calf cows
}

\author{
M. Modzelewska-Kapituła ${ }^{1 \#}$, Z. Nogalski ${ }^{2}$ \& A. Kwiatkowska ${ }^{3}$ \\ ${ }^{1}$ Department of Industrial Commodity, Basics of Techniques and Energy Management, Faculty of Food Sciences, \\ University of Warmia and Mazury in Olsztyn, Plac Cieszyński 1, 10-719 Olsztyn, Poland, \\ ${ }^{2}$ Department of Cattle Breeding and Milk Evaluation, Faculty of Animal Bioengineering, University of Warmia and \\ Mazury in Olsztyn, ul. Oczapowskiego 5, 10-719 Olsztyn, Poland, \\ ${ }^{3}$ Department of Meat Technology and Chemistry, Faculty of Food Sciences, \\ University of Warmia and Mazury in Olsztyn, Plac Cieszyński 1, 10-719 Olsztyn, Poland
}

(Received 28 May 2014; Accepted 13 November 2014; First published online 28 November 2014)

Copyright resides with the authors in terms of the Creative Commons Attribution 2.5 South African Licence.
See: http://creativecommons.org/licenses/by/2.5/za
Condition of use: The user may copy, distribute, transmit and adapt the work, but must recognise the authors and the South African
Journal of Animal Science.

\begin{abstract}
The aim of the study was to compare slaughter value, collagen profile, shear force and sensory quality of muscles originating from carcasses of heifers and single-calf cows of Polish Holstein-Friesian $x$ Limousine crossbreds. Eight heifers (540 days old) and eight single-calf cows (836 days old), which were produced in a semi-intensive system, were included in the study. Single-calf cows were heavier than the heifers, which had higher dressing percentages and average daily gains. Calving and age at slaughter did not influence cooking loss of semimembranosus (SEM) and infraspinatus (INF) muscles or the shear force of SEM. The ventral part of the INF muscle from single-calf cows exhibited higher shear force values. In both muscles, higher water-soluble and lower acid-soluble collagen contents were noted in heifers compared with single-calf cows. There were no differences in sensory quality of SEM obtained from the carcasses of singlecalf cows and heifers, whereas cross-section appearance, tenderness, juiciness and overall acceptability of INF were scored higher for single-calf cows than for heifers. Thus, it can be concluded that heifers and single-calf cows produce meat with similar eating quality.
\end{abstract}

Keywords: Beef, crossbreds, connective tissue, meat, sensory quality

\#Corresponding author: monika.modzelewska@uwm.edu.pl

\section{Introduction}

Currently, beef producers crossbreed dairy cows with beef bulls to obtain progeny characterized by higher fattening ability and slaughter, and meat characterized by better eating quality than that obtained from dairy cattle (Nogalski \& Kijak, 2001). Hoving-Bolink et al. (1999) suggested that heifers produced by mating dairy cows to beef bulls could be used as single-calf cows in order to increase the market share of highquality beef. Moreover, using heifers as single-calf cows results in an increase in beef production because single-calf cows obtain a higher bodyweight (BW) at the end of fattening than heifers (Lucero-Borja et al., 2014). Additionally, the calves, as the progeny of single-calf cows, are valuable and suitable for fattening. Currently, it has great significance because in dairy herds, which are the natural environment for raising calves for fattening, the period during which cows are used is decreasing along with the number of emerging 
calves (Wroński, 1999). Biologically, the single-calf heifer system is more efficient than traditional cow-calf operations because the younger growing female uses a smaller proportion of energy intake for maintenance (Bourdon \& Brinks, 1987). Thus, the beef production system that combines reproduction and finishing of single-calf cows decreases maintenance energy per unit beef production and is therefore more profitable than the traditional cow-calf production system (Zembayashi, 2001).

However, single-calf cows are slaughtered at an older age than heifers. An animal's age is one of the factors affecting beef quality. As animals become older, the beef they produce becomes less tender owing to increased stability (mechanical and thermal) of collagen (Tatum, 2011). Collagen, being a connective tissue protein, accounts for about $1.5 \%-10 \%$ of muscle dry weight and is composed of three polypeptide chains ( $\alpha$ constituents) (Lepetit, 2008). Between the chains, intramolecular bounds are created during the animal's life and, as a result, $\beta$ (when two achains are linked) and $y$ (when three achains are linked) constituents are created. These forms differ in their solubility: $\alpha$ constituents are soluble in inert salt solutions, whereas $\beta$ and y constituents are soluble in acetic acid solutions and citric buffer. Between collagen molecules inside fibrils, intermolecular covalent bonds (also called 'cross-linking') exist (Reich, 1970). In beef obtained from young cattle (12 - 18 months old) intramuscular collagen is soluble and has a high proportion of reducible heatlabile crosslinks. Such collagen easily hydrolyses during cooking and forms gelatine, which reduces the effect of collagen on meat tenderness (Tatum, 2011). During the life of animals, the nature of the crosslinks changes from reducible into non-reducible, which decreases the thermal solubility of collagen (Reich, 1970) and the higher proportion of thermally stable collagen in muscles, the greater their toughness (Purslow, 2005). Changes in tenderness or collagen solubility owing to animal age have been investigated by many researchers. Xiong et al. (2007) studied the influence of the age of mature cows (from 2 to 12 years) on the quality of longissimus dorsi (LD) steaks and reported that steaks produced from 10- to 12-year-old cows showed higher $(P<0.05)$ WBSF values than steaks from 6 - to 8-year-olds and from 2 - to 4-year-old animals. The authors noted that the steaks from 2- to 4-year-old cows tended to be more tender than those from 6- to 8-year-old cows. However, when comparing cattle whose age at slaughter was lower than 30 months, conflicting results were reported. Okumura et al. (2012) found that soluble collagen content and collagen solubility for 20-month steers were greater than at 25 and 30 months, whereas tenderness and juiciness at 25 months were greater than at 20 months. Du Plessis et al. (2007) reported that the meat from 30-monthold steers was less tender and had higher Warner-Bratzler shear force (WBSF) values than 18-month-old steers. On the other hand, Acheson et al. (2014) found no differences in tenderness, juiciness, flavour or WBSF between LD steaks from carcasses classified as A maturity and steaks from B-C maturity cattle carcasses, whose dental ages were less than 30 months.

Beef carcass muscles differ in their collagen content and many quality traits, such as shape, weight, colour and tenderness (Jeremiah et al., 2003a). The infraspinatus (INF) is one of the chuck muscles of a beef carcass. It is characterized by a high intramuscular connective tissue content (Hildrum et al., 2009) and good tenderness of lean tissue (Highfill et al., 2012). The semimembranosus (SEM) is one of the round muscles, which have less intramuscular connective tissue and are less tender than the chuck muscles (Hildrum et al., 2009). According to our earlier report, SEM muscle is characterized by higher amounts of insoluble collagen and a lower amount of total soluble collagen (\% of total collagen) than INF muscle (Modzelewska-Kapituła \& Nogalski, 2014). As shown by Schönfeldt \& Strydom (2011), collagen solubility and shear force resistance were the most important discriminants between the cuts obtained from animals slaughtered at different ages. Taking into consideration the benefits of the single-calf system, the changes in tenderness owing to animal age, and the possible effect of gestation on carcass value and meat quality, the aim of the present study was to investigate the differences in collagen solubility, shear force and eating quality of two bovine muscles, SEM and INF, between young heifers and single-calf cows. 


\section{Material and Methods}

The experimental materials comprised 16 animals, including heifers $(n=8)$ and single-calf cows $(n=$ 8), produced by crossing Polish Holstein-Friesian cows with Limousine bulls. Calves (16 females) from 2 to 3 weeks old were placed in a rearing facility at the Agricultural Experiment Station in Bałcyny, Poland. The calves were fed milk replacer, hay and concentrate, followed by haylage. Starting at seven months old, animals were fattened semi-intensively and were fed ad libitum a total mixed ration (TMR), composed of grass silage and concentrates. In Table 1, the chemical composition and nutritional values of each ingredient used in the TMR preparation are presented.

Table 1 Chemical composition and nutritional value of ingredients of experimental diets (mean \pm standard deviation)

\begin{tabular}{|c|c|c|c|c|c|}
\hline Specification & Silage & Triticale & Rapeseed meal & Concentrate I & Concentrate II \\
\hline Dry matter (\%) & $39.7 \pm 10.9$ & $88.1 \pm 0.22$ & $88.7 \pm 0.21$ & $88.4 \pm 0.7$ & $88.6 \pm 0.8$ \\
\hline \multicolumn{6}{|c|}{ On dry matter basis (\%) } \\
\hline Organic matter & $92.0 \pm 3.1$ & $98.1 \pm 0.25$ & $92.7 \pm 0.27$ & $93.2 \pm 1.3$ & $92.5 \pm 1.8$ \\
\hline Crude protein & $14.1 \pm 1.1$ & $13.3 \pm 0.70$ & $38.8 \pm 0.85$ & $18.9 \pm 1.5$ & $16.3 \pm 0.7$ \\
\hline $\mathrm{NDF}^{1}$ & $56.9 \pm 5.2$ & $19.3 \pm 0.10$ & $31.0 \pm 0.11$ & $20.2 \pm 1.1$ & $18.4 \pm 0.8$ \\
\hline $\mathrm{ADF}^{2}$ & $38.7 \pm 5.9$ & $4.4 \pm 0.02$ & $22.8 \pm 0.12$ & $7.2 \pm 0.6$ & $3.1 \pm 0.8$ \\
\hline $\mathrm{DOMD}^{3}$ & $74.1 \pm 5.6$ & $93.2 \pm 2.6$ & $84.8 \pm 0.41$ & - & - \\
\hline $\mathrm{UFV}^{4}$ & $0.08 \pm 0.00$ & $0.12 \pm 0.00$ & $0.10 \pm 0.00$ & $0.12 \pm 0.00$ & $0.12 \pm 0.00$ \\
\hline $\operatorname{PDIN}^{5}$ & $8.2 \pm 0.6$ & $8.9 \pm 0.03$ & $25.9 \pm 0.09$ & $12.2 \pm 0.2$ & $11.2 \pm 0.5$ \\
\hline $\mathrm{PDIE}^{6}$ & $6.9 \pm 0.2$ & $10.9 \pm 0.08$ & $16.3 \pm 0.10$ & $13.0 \pm 0.5$ & $12.1 \pm 0.5$ \\
\hline
\end{tabular}

$\mathrm{N}=9$ for silage; $\mathrm{N}=3$ for triticale and rapeseed meal; $\mathrm{N}=7$ for concentrates I and II.

${ }^{1}$. neutral detergent fibre; ${ }^{2}$ acid detergent fibre; ${ }^{3}$ digestible organic matter in dry matter; ${ }^{4}$ meat fodder units; ${ }^{5}$ protein digested in the small intestine when rumen fermentable $\mathrm{N}$ is limiting; ${ }^{6}$ protein digested in the small intestine when rumen fermentable energy is limiting; fermentation characteristics of silage: $\mathrm{pH} 4.8 \pm 0.3$; lactic acid, $5.4 \pm 2.0 \%$ dry matter; volatile fatty acids, $2.7 \pm 0.5 \%$ dry matter; water soluble carbohydrates, $8.2 \pm 4.8 \%$ dry matter; $\mathrm{N}^{-\mathrm{NH}_{3}} \% \mathrm{~N}$, $10.3 \pm 6.7$; true protein $51.8 \pm 4.6 \%$ crude protein.

Animals with BW below $300 \mathrm{~kg}$ were fed a TMR containing concentrate I (triticale, 71\%; rapeseed meal, $25 \%$ and premix, 4\%), and animals with BW above $300 \mathrm{~kg}$ were fed a TMR containing concentrate II (triticale, 77\%; rapeseed meal, 19\% and premix, 4\%). A commercial mineral-vitamin premix for fattening cattle was included in the diet (Cargill Poland Ltd, Kiszkowo, Poland, code of product 7619), consisting per kg of: $235 \mathrm{~g} \mathrm{Ca} ; 79 \mathrm{~g} \mathrm{Na} ; 48 \mathrm{~g} \mathrm{P} ; 28 \mathrm{~g} \mathrm{Mg} ; 500$ mg Fe; 2000 mg Mn; 375 mg Cu; 3750 mg Zn; 50 mg I; $12.5 \mathrm{mg}$ Co; $12.5 \mathrm{mg}$ Se; $250000 \mathrm{IU}$ vitamin A; $50000 \mathrm{IU}$ vitamin $\mathrm{D}_{3} ; 1000 \mathrm{mg}$ vitamin E; $909 \mathrm{mg}$ DL alphatocopherol. The silage-to-concentrate ratio, on a dry matter basis, was $25: 75$ (Table 2). The ratio was adjusted every four weeks, based on analysis of grass silage for its dry matter content. The share of mixtures in portions was calculated based on energy density of portions recommended in the system of evaluation and nutrition INRA (1993), according to the models for beef and dairy $\mathrm{x}$ beef crossbred heifers.

The heifers $(n=16)$ were kept in pens and group-fed according to a TMR system. Eight heifers were fattened until the animals were 18 months old, then they were slaughtered. The other eight heifers $(14.9 \pm$ 0.67 months old, BW $430 \pm 15.6 \mathrm{~kg}$ ) were inseminated with Limousine bull semen. After calving, the 
Table 2 Chemical composition and nutritional value of total mixed ration (TMR)

\begin{tabular}{lcc}
\hline Specification & $<\mathbf{3 0 0} \mathbf{~ k g ~ B W}$ & $>\mathbf{3 0 0} \mathbf{~ B W}$ \\
\hline Grass silage (\%) & $75^{\star}$ & 75 \\
Concentrate I (\%) & 25 & - \\
Concentrate II (\%) & - & 25 \\
Dry matter (\%) & 51.9 & 51.9 \\
On dry matter basis (\%) & & \\
Crude protein & 15.3 & 14.6 \\
NDF $^{1}$ & 47.3 & 46.6 \\
ADF $^{2}$ & 30.8 & 29.8 \\
UFV $^{3}$ & 0.09 & 0.09 \\
PDIN $^{4}$ & 9.2 & 9.0 \\
PDIE $^{5}$ & 8.4 & 8.2
\end{tabular}

\footnotetext{
${ }^{1}$ Neutral detergent fibre; ${ }^{2}$ acid detergent fibre; ${ }^{3}$ meat fodder units; ${ }^{4}$ protein digested in the small intestine when rumen fermentable $\mathrm{N}$ is limiting; ${ }^{5}$ protein digested in the small intestine when rumen fermentable energy is limiting.

$\star 75: 25$ in dry matter and 87:13 in fresh matter. BW: bodyweight.
}

weaning of calves from single-calf cows (24.1 \pm 0.74 -months old) was at $104 \pm 2.6$ days. The calves then gained $148.7 \pm 7.6 \mathrm{~kg}$ in BW. Weaning calves were assigned to further fattening, whereas their mothers (single-calf cows) were transported to a meat processing plant where they were kept in individual stalls with access to water for 15 - 20 hours. The animals were weighed before slaughter, and all slaughter and postslaughter processes were carried out in accordance with the current meat industry regulations (Council Regulation (EC) No 1099/2009 of 24 September 2009 on the protection of animals at the time of killing). The animals were stunned, dressed, and halved along with the spine into two half-carcasses that were then chilled for 96 hours at $4{ }^{\circ} \mathrm{C}$. Electric stimulation was not applied to the carcasses. Half-carcasses were weighed using in-line automatic weight within an accuracy of $0.5 \mathrm{~kg}$, and conformation and fatness were evaluated based on the EUROP system criteria by a trained grader (Kien, 2004). The protocol for animal research was approved by the Ethics Committee of the University of Warmia and Mazury.

The INF and SEM muscles were removed from each carcass (INF, $n=16$ and SEM $n=1696 \mathrm{~h}$ post mortem). The muscles were delivered to the laboratory of the Department of Meat Technology and Chemistry in refrigerated isothermal containers. The delivery lasted about $1 \mathrm{~h}$. After delivery, the muscles were trimmed of all external connective tissue (epimysium) and weighed. Owing to the non-homogeneity of the connective tissue distribution within the INF, the whole muscle (1222 $\pm 204 \mathrm{~g}$ and $1447 \pm 364 \mathrm{~g}$ for heifers and single-calf cows, respectively) was used for the experiment. In the SEM muscle, which has considerable uniform connective tissue distribution, localized mainly in its extremities, a central part of the muscle (weight $981 \pm 194 \mathrm{~g}$ and $1118 \pm 36 \mathrm{~g}$ for heifers and single-calf cows, respectively) was used. The muscles were placed in a cool convectional-steam oven (Küppersbusch CPE 110, Küppersbusch Großküchentechnik $\mathrm{GmbH}$, Gelsenkirchen, Germany) and subjected to thermal treatment at $180{ }^{\circ} \mathrm{C}$ to obtain $80^{\circ} \mathrm{C}$ in the centre of the muscles. This temperature was used to obtain well-done roasts (Li et al., 2010) with no colour differences between their centre and peripheral area. In consumers' opinion, if the centre of a roast is redder than its peripheral area, this indicates that cooking time was too short. The internal temperature of the muscles was continuously controlled using a thermometer (connected to the oven), which was placed in the central part of each muscle. After thermal treatment, the muscles were cooled to room temperature (about $20^{\circ} \mathrm{C}$, about $3 \mathrm{~h}$ ) and then in a refrigerator to $3 \pm 2{ }^{\circ} \mathrm{C}$ (for about $12 \mathrm{~h}$ ). 
Cooking loss, collagen profile, WBSF and the sensory quality of the cooked meat were determined. The sampling protocol was as follows. First, the samples for sensory assessment were cut from each end of the cooled muscles (fragments about $4 \mathrm{~cm}$ long). From the remaining cooked meat, the crusted cooked surface was removed with a knife. The samples for shear force determination were cut. The remaining cooked meat was ground, along with the crusted cooked surface cut earlier, and samples for collagen profile analyses were taken. Cooking loss (evaporative and drip) was calculated as the ratio of the difference between the meat weight before and after cooking to the meat weight before cooking and was expressed in percentage.

Before analyses, the meat was ground twice through a $3 \mathrm{~mm}$ mesh. The total collagen content was determined according to Reich (1970), water-soluble collagen content according to Hill (1966), and insoluble collagen content according to the Blomfield \& Farrar (1964) method with modifications (ModzelewskaKapituła \& Nogalski, 2014). The amount of hydroxyproline was determined according to Reich (1970). The collagen content was calculated from the hydroxyproline content using the coefficient 7.25. For each hydrolysate, two parallel analyses of hydroxyproline were performed. The amount of collagen soluble in $0.5 \mathrm{M} \mathrm{CH}_{3} \mathrm{COOH}$ (acid-soluble) was calculated as the difference between the total collagen and the sum of water-soluble and insoluble collagen contents, whereas total soluble collagen was calculated as the sum of water- and acid-soluble collagen contents. The share of each collagen fraction (\%) was calculated for total collagen content.

The WBSF values (N) were measured using an Instron 5965 (Instron, Norwood, Mass., USA) equipped with a shear blade. Cylindrical core samples $(1.27 \mathrm{~cm}$ diameter, about $40 \mathrm{~mm}$ long) were cut out with a cork borer in the direction of muscle fibres. The shear blade ( $\mathrm{V}$-shaped, with a triangular aperture of $60^{\circ}$ ) was applied perpendicularly to the fibre direction at a crosshead speed of $2 \mathrm{~mm} / \mathrm{s}$ (Walsh et al., 2010). The test was done on meat at room temperature (about $18^{\circ} \mathrm{C}$ ). The measured data were evaluated using Bluehill 3 software (Instron, Norwood, Mass., USA). Five samples were cut from each SEM muscle, while, separate samples from each INF muscle were cut from the ventral $(n=5)$ and dorsal $(n=5)$ part of the muscle (meat tissue) along with additional samples containing the connective tissue seam from the ventral $(n=5)$ and dorsal $(n=5)$ parts of the muscle. The procedure resulted from the non-homogeneity of INF muscle, which has a connective seam with a different thickness in the dorsal and ventral parts of the muscle (Modzelewska-Kapituła et al., 2012).

Sensory analyses were conducted using samples cut from cooked muscles. A fragment about $4 \mathrm{~cm}$ long was cut from each end of the cooled muscles and sliced with a slicing machine (Ma-Ga S 712p, Automatic slicing machine, Bydgoskie Zakłady Maszyn Gastronomicznych, Bydgoszcz, Poland) into $2 \mathrm{~mm}$ thick slices. The temperature of the samples subjected to evaluation was about $10^{\circ} \mathrm{C}$. Roast beef, especially in thin slices (as in the study), is an alternative to sausages and is eaten cold with bread. This method of roast consumption is popular in Poland. Expert sensory assessment was conducted by 5 - 10 panellists (on average, 6 panellists) experienced in sensory evaluation of meat products and familiar with the current product. A comparison between meat samples was conducted according to Polish Standard PN-ISO 4121 (1998). A scale of 1 - 9 was used in the sensory evaluation. Panellists scored each sample for appearance (1, not acceptable; 9 , extremely acceptable); tenderness (1,extremely tough; 9 , extremely tender); juiciness (1, extremely dry; 9 , extremely juicy); taste (1, extremely bland, atypical; 9 , extremely intense, typical); aroma (1, extremely bland, atypical; 9 , extremely intense, typical); colour (1, uneven, red, inappropriate; 9 , even, typical, acceptable); and overall acceptability (1, not acceptable; 9 , extremely acceptable). Samples were randomly distributed on white plates for evaluation. Water and bread were provided for cleansing the palate.

To compare the mean values, a Student t-test for independent variables was applied. The significance of the differences was reported at $P<0.01$ and $<0.05$. All calculations were performed using Statistica 10 (StatSoft Inc., Tulsa, Okla., USA). 


\section{Results and Discussion}

Single-calf cows were significantly heavier than heifers (Table 3), whereas heifers showed higher $(P$ $<0.01$ ) dressing percentage (about 2.09\%) than single-calf cows. The lower dressing percentage of singlecalf cows compared with heifers might be caused by their higher age at slaughter, and therefore higher weight of gastrointestinal and reproductive tracts. The influence of cow's age on dressing percentage is supported by the results obtained by Litwińczuk et al. (1991), who reported that dressing percentage of single-calf cows of the same genotype as investigated in the present study, slaughtered at the age from 30 to 32 months old, was lower than noted in the present study for 27 -month-old single-calf cows (53.2\% vs. $55.2 \%$, respectively). Cabaraux et al. (2004) also showed that the dressing percentage of heifer (27-monthold) carcasses was significantly higher than those from cows after two and four calvings (50 and 82 months old, respectively). Galli et al. (2008) showed significant effect of age on dressing percentage in cows slaughtered at 3, 4-5, $6-8$, and 12 years old, with a trend toward reduced dressing percentage with the increasing cow age. The differences in dressing percentage noted in the present study between heifers and single-calf cows were presumably caused by the differences in the somatic development of the animals. The somatic development of cattle ends when animals are 4 - 5 years old. After that, the internal organs of cattle are growing. Reiling et al. (1996) found that single-calf cows (36 months old) had a significantly greater percentage of kidney, pelvic and heart fat than heifers (24 months old). In our study, the difference in age at slaughter between heifers and single-calf cows was 10 months, which may have affected the weight of the gastrointestinal tract of the animals. On the other hand, according to Fiems et al. (2003), as far as dressing percentage is concerned, animal age is less important than that animals are pregnant. The higher weight of gastrointestinal tract can be caused by higher deposits of internal fat in single-calf cows. As shown by Patterson et al. (2004), during gestation a larger amount of internal fat is deposited in the body of single-calf cows, which is one of the reasons for a lower dressing percentage of single-calf cows than heifers, when slaughtered at the same age. Moreover, the cows had heavier udders than heifers (Patterson et al., 2004). Although in the present study the weight of udders was not recorded, this could affect the dressing percentage.

There were no differences in the conformation and fatness scores between heifers and single-calf cows. The results are similar to those reported by Zembayashi (2001), who found no significant differences

Table 3 Body weight (BW) at beginning and end of fattening and selected parameters of young heifers and single-calf heifer carcasses (least squares means \pm standard deviation)

\begin{tabular}{lccc}
\hline Trait & Heifers & Single-calf cows & Significance \\
\hline BW at the beginning of fattening $(\mathrm{kg})$ & $213.2 \pm 22.75$ & $214.5 \pm 18.80$ & $\mathrm{NS}$ \\
BW at the end of fattening $(\mathrm{kg})$ & $478.3 \pm 20.49$ & $610.0 \pm 33.66$ & $\star *$ \\
Average daily gain $(\mathrm{kg})$ & $0.792 \pm 0.069$ & $0.632 \pm 0.056$ & $\star \star$ \\
Age at slaughter (days) & $544.7 \pm 7.39$ & $836.3 \pm 23.93$ & $\star *$ \\
BW before slaughter (kg) & $444.9 \pm 19.47$ & $564.1 \pm 31.72$ & $* *$ \\
Dressing percentage (\%) & $57.33 \pm 0.72$ & $55.24 \pm 1.14$ & NS \\
${ }^{1}$ Conformation score (pts) & $7.3 \pm 1.21$ & $8.0 \pm 1.10$ & NS \\
${ }^{2}$ Fatness score (pts) & $8.2 \pm 1.94$ & $8.5 \pm 3.21$ & \\
\end{tabular}

\footnotetext{
${ }^{1}$ EUROP conformation: 1 to 15 , with 1 = very lean, and $15=$ muscled outstanding.

${ }^{2}$ EUROP degree of fat cover: 1 to 15 , with 1 = very low, and $15=$ very fat.

** mean values in rows differ at $\mathrm{P}<0.01$; * mean values in rows differ at $\mathrm{P}<0.05$; NS: non significant differences.
} 
in carcass and longissimus thoracis et lumborum (LT) quality traits (intramuscular fat content, colour, fatty acid composition) between maiden heifers and single-calf cows. Patterson et al. (2004) reported that carcass conformation was not affected by gestation, but improved with increased heifer age. On the other hand, the positive effect of gestation on carcass fatness was noted by Field et al. (1996), who determined the slaughter value of heifers and single-calf cows slaughtered at the same age.

The cooking losses of roasts produced from SEM and INF muscles are listed in Table 4. Muscles from heifers and single-calf cows did not differ in cooking loss for both muscles. The lack of difference in cooking loss between the muscles obtained from heifers and cows was reported by Cabaraux et al. (2004) and Galli et al. (2008), whereas Patterson et al. (2004) showed that although gestation did not influence cooking loss of LT muscle, the age of animals did. Cooking loss is affected by numerous factors such as the chemical composition of the meat, thermal processing method, and final internal meat temperature (ModzelewskaKapituła et al., 2012) as well as pre- and post-slaughter operations (Ferguson \& Warner, 2008). Abgeniga et al. (2013) noted that cooking losses were affected by stunning method and the rates of $\mathrm{pH}$ and temperature decline, whereas Jama et al. (2008) reported that post-mortem ageing decreases cooking loss. In our study, since all animals were slaughtered under the same conditions, and the muscles were cooked using the same method, no differences in cooking loss were observed.

The values of WBSF for SEM and INF muscles are presented in Table 4. According to the USDA standards for beef tenderness certification, meat with a WBSF value of $43.25 \mathrm{~N}$ or lower can be labelled "Certified Tender" and meat of $38.25 \mathrm{~N}$ and lower "Certified Very Tender" (ASTM, 2011, as cited by Corbin et al., 2015). The SEM muscle from heifers and single-calf cows can be thus classified as tender, whereas INF muscle from both treatments can be classified as very tender. There were no differences in WBSF values for SEM muscles obtained from carcasses of heifers and single-calf cows. Similarly, Cabaraux et al. (2004), Patterson et al. (2004) and Galli et al. (2008) noted no differences in WBSF values of LT muscles from carcasses of heifers and cows. In the INF, the muscles from single-calf cows showed higher values of WBSF for the ventral part of the muscle (meat and connective tissue seam, $P<0.05, P<0.01$, respectively) compared with heifers. In support of current findings, Waggoner et al. (1990) reported a negative effect of calving on WBSF values, which were higher in single-calf cows compared with young (17-month-old) and 29-month-old heifers. However, as shown by Kamatara et al. (2013), post-mortem ageing of beef

Table 4 Cooking loss (\%) and Warner-Bratzler shear force $(\mathrm{N})$ of roast semimembranosus (SEM) and infraspinatus (INF) muscles of Polish Holstein-Friesian $x$ Limousine crossbred young heifers $(n=8)$ and single-calf cows $(n=8)$ (mean \pm standard deviation)

\begin{tabular}{lccc}
\hline Muscle & Heifers & Single-calf cows & Significance \\
\hline SEM muscle & & & \\
Cooking loss (\%) & $39.9 \pm 3.9$ & $41.3 \pm 0.9$ & NS \\
WBSF (N) & $40.2 \pm 9.1$ & $42.6 \pm 7.8$ & NS \\
INF muscle & $38.0 \pm 2.4$ & $39.1 \pm 2.4$ & NS \\
$\quad$ Cooking loss (\%) & & & \\
WBSF (N) & $24.1 \pm 5.6$ & $27.0 \pm 6.0$ & $*$ \\
Ventral part (meat) & $29.0 \pm 11.4$ & $50.8 \pm 20.1$ & NS \\
Ventral part (seam) & $23.3 \pm 4.1$ & $23.3 \pm 3.8$ & NS \\
Dorsal part (meat) & $21.8 \pm 4.6$ & $23.9 \pm 5.5$ & \\
Dorsal part (seam) & & & \\
\end{tabular}

** mean values in rows differ at $P<0.01$; * mean values in rows differ at $P<0.05$; NS: insignificant differences. 
significantly decreases its WBSF values and minimizes the differences in tenderness between meat obtained from animals of different breeds and feeding systems. Thus, the application of post-mortem ageing will presumably eliminate the differences in WBSF values of the ventral part of INF muscles from heifers and single-calf cows.

Table 5 shows the collagen profile of roast SEM and INF muscles obtained from heifers and singlecalf cows. In the SEM muscle, the single-calf cows had a higher total $(P<0.01)$, acid soluble $(\mathrm{mg} / 100 \mathrm{~g}, \% ; P$ $<0.01)$, total soluble $(\mathrm{mg} / 100 \mathrm{~g} ; P<0.01)$ and insoluble $(\mathrm{mg} / 100 \mathrm{~g} ; P<0.05)$, and a lower water soluble ( $\mathrm{mg} / 100 \mathrm{~g}, \% ; P<0.01)$ collagen content than heifers. In the INF muscle, single-calf cows and heifers differed only in terms of water soluble $(\mathrm{mg} / 100 \mathrm{~g}, \% ; P<0.01)$ and acid soluble $(\% ; P<0.05)$ collagen fractions. In single-calf cow INF muscles, higher acid-soluble and lower water-soluble collagen content were noted compared to heifers. The differences in collagen solubility in SEM did not affect WBSF values. Similar results were reported by Oury et al. (2009), who noted that WBSF values of rectus abdominis (RA) muscle were correlated with total collagen content, whereas no correlation was found between WBSF and soluble collagen content. On the contrary, in the INF muscle, the lower amount and share of water-soluble collagen noted in single-calf cows compared with heifers affected the WBSF values of the ventral part of the muscle, most significantly its connective tissue seam (Table 4), which is wider than the connective tissue seam from the dorsal part (Modzelewska-Kapituła et al., 2012). This might indicate that WBSF values of connective tissue depend on the amount of water-soluble collagen. During meat cooking, a thermohydrolysis of collagen occurs (Jeremiah et al., 2003b), and as a result the amount of water-soluble collagen in cooked meat is higher than in raw (Dąbrowska et al., 2010). Thus, the connective tissue seam from heifers, of which the collagen was more water soluble than from single-calf cows, had lower WBSF values. As far as age-related increases in heat-stability of collagen are concerned, Schönfeldt \& Strydom (2011) concluded that the higher the collagen content of a cut, the more it will be affected by cattle age, even if the collagen solubility is high and the correct cooking method is used. The results obtained in the present study regarding collagen solubility may indicate that the amount of $\alpha$ chains was higher, whereas the $\beta$ and $y$ constituents were lower in collagen fibres of heifers than in single-calf cows. The differences were noted in both muscles, which indicates that the formation of intramolecular bonds in collagen molecules does not depend on collagen concentration of muscle or its location in the animal body. In SEM muscle, a higher amount of insoluble collagen was noted in single-calf cows compared with heifers, which indicates that in single-calf cow muscle, a higher number of intermolecular bonds between collagen molecules were created. This observation might suggest that the formation of intermolecular bonds in collagen fibres during an animal's life depends on muscle composition (the lower the collagen content, the higher the amount of the intermolecular bonds). The lower solubility of collagen in single-calf cows' muscles compared with heifers was not surprising, since single-calf cows were older than heifers. Schreurs et al. (2008) reported that the degree of maturity, estimated as the proportion of BW at sampling divided by mature BW, influenced insoluble collagen content in muscles from different parts of the carcass (Iongissimus dorsi, semitendinosus and triceps brachii). They concluded that the development of muscle characteristics is different for each muscle, which was also noted in the present study. However, Oury et al. (2009) reported no differences in the amount of soluble and total collagen in RA muscle among 26- to 43-month-old heifers. Similar results were reported by Cabaraux et al. (2004), who studied the collagen content (\% dry matter) in LT muscle from heifers (27-months-old) and cull cows (50 and 82 months old). In the present study, the increase in total collagen content in single-calf cows compared with heifers was noted only in the SEM muscles, which have lower total collagen content than INF muscle (Modzelewska-Kapituła et al., 2012). This can be explained by the higher age of single-calf cows than heifers. The increase in total collagen content with animal age was also noted by Bureš \& Bartoň (2012).

The results of sensory analysis of SEM and INF roasts for young heifers and single-calf cows are listed in Table 6. The INF roasts obtained from the single-calf cows gained higher scores for cross-section 
Table 5 Collagen profile (mean \pm standard deviation) of roast semimembranosus (SEM) and infraspinatus (INF) muscles of Polish Holstein-Friesian $x$ Limousine crossbred young heifers $(n=8)$ and single-calf cows $(\mathrm{n}=8)$

\begin{tabular}{|c|c|c|c|c|}
\hline Attribute & Unit & Heifers & Single-calf cows & Significance \\
\hline \multicolumn{5}{|l|}{ SEM muscle } \\
\hline Total collagen & $\mathrm{mg} / 100 \mathrm{~g}$ & $877.5 \pm 164.7$ & $1037.9 \pm 233.2$ & ** \\
\hline \multirow[t]{2}{*}{ Water soluble } & $\mathrm{mg} / 100 \mathrm{~g}$ & $187.4 \pm 84.7$ & $132.6 \pm 58.4$ & $\star \star$ \\
\hline & $\%$ & $22.2 \pm 12.1$ & $12.7 \pm 4.9$ & ** \\
\hline \multirow[t]{2}{*}{ Acid soluble } & $\mathrm{mg} / 100 \mathrm{~g}$ & $549.2 \pm 182.4$ & $725.4 \pm 148.3$ & ** \\
\hline & $\%$ & $61.1 \pm 12.1$ & $71.1 \pm 8.9$ & $\star *$ \\
\hline \multirow[t]{2}{*}{ Total soluble } & $\mathrm{mg} / 100 \mathrm{~g}$ & $733.1 \pm 151.0$ & $853.5 \pm 167.7$ & $\star \star$ \\
\hline & $\%$ & $83.0 \pm 4.4$ & $83.3 \pm 5.7$ & NS \\
\hline \multirow[t]{2}{*}{ Insoluble } & $(\mathrm{mg} / 100 \mathrm{~g})$ & $147.6 \pm 37.3$ & $171.8 \pm 64.9$ & * \\
\hline & $\%$ & $17.0 \pm 4.4$ & $16.6 \pm 6.0$ & NS \\
\hline \multicolumn{5}{|l|}{ INF muscle } \\
\hline Total collagen & $\mathrm{mg} / 100 \mathrm{~g}$ & $1879.8 \pm 401.9$ & $1925.1 \pm 418.8$ & NS \\
\hline \multirow[t]{2}{*}{ Water soluble } & $\mathrm{mg} / 100 \mathrm{~g}$ & $855.6 \pm 274.5$ & $684.8 \pm 315.6$ & $\star \star$ \\
\hline & $\%$ & $45.6 \pm 13.6$ & $36.4 \pm 15.6$ & $\star \star$ \\
\hline \multirow[t]{2}{*}{ Acid soluble } & $\mathrm{mg} / 100 \mathrm{~g}$ & $780.8 \pm 352.1$ & $918.8 \pm 336.7$ & NS \\
\hline & $\%$ & $40.9 \pm 14.5$ & $49.1 \pm 14.5$ & * \\
\hline \multirow[t]{2}{*}{ Total soluble } & $\mathrm{mg} / 100 \mathrm{~g}$ & $1634.5 \pm 402.4$ & $1584.9 \pm 380.3$ & NS \\
\hline & $\%$ & $87.2 \pm 3.6$ & $82.9 \pm 14.5$ & NS \\
\hline \multirow[t]{2}{*}{ Insoluble } & $(\mathrm{mg} / 100 \mathrm{~g})$ & $236.5 \pm 51.2$ & $255.2 \pm 62.6$ & NS \\
\hline & $\%$ & $12.9 \pm 3.6$ & $13.8 \pm 3.8$ & NS \\
\hline
\end{tabular}

** mean values in rows differ at $\mathrm{P}<0.01$; * mean values in rows differ at $\mathrm{P}<0.05$; NS: insignificant differences.

appearance $(P<0.01)$, tenderness $(P<0.05)$, juiciness $(P<0.01)$ and overall acceptability $(P<0.05)$ than heifers. No differences in the sensory quality of SEM were noted between heifers and single-calf cows. There are conflicting reports concerning the eating quality of muscles obtained from heifers and single-calf cows or animals at different ages. Oury et al. (2009) reported that the age of heifers (from 26 to 43 months old) significantly negatively influenced RA tenderness, but had no effect on its juiciness or flavour intensity. Lucero-Borja et al. (2014) found no differences in flavour, juiciness, odour or tenderness of LT muscles from heifers and cows. Similar results were reported by Galli et al. (2008) for juiciness and flavour of LT muscle obtained from heifers and cows. The lack of cattle age effect on tenderness, juiciness, firmness and chewiness was noted by Moloney et al. (2011), who investigated the sensory quality of LT muscles from 25and 30-month-old steers. However, Galli et al. (2008), who evaluated the sensory quality of LT muscle obtained from heifers and cows of different ages, found that there was a significant age class effect on connective tissue scores and attributed it to an increase in intermolecular cross links of the collagen fibres with cow age.

In the present study, the INF muscle from single-calf cows were characterized by higher scores for sensorial tenderness and higher values of WBSF compared with heifers. This inconsistency in the results for tenderness obtained can be explained because sensory attributes of meat such as tenderness and juiciness appear to be interrelated. Juicier meat is perceived to be more tender than less juicy (Špehar et al., 2008; Corbin et al., 2015). In addition, Dubost et al. (2013) concluded, the higher juiciness of beef is associated 
Table 6 Results (mean \pm standard deviation) of sensory analysis of roast semimembranosus (SEM) and infraspinatus (INF) muscles of Polish Holstein-Friesian $x$ Limousine crossbred young heifers $(n=8)$ and once-calved cows $(n=8)$

\begin{tabular}{lccc}
\hline Attribute & Heifers & Single-calf cows & Significance \\
\hline SEM muscle & $7.7 \pm 1.1$ & $7.6 \pm 0.8$ & NS \\
Cross-section appearance & $6.4 \pm 1.2$ & $6.3 \pm 1.1$ & NS \\
Tenderness & $5.7 \pm 1.9$ & $5.5 \pm 1.5$ & NS \\
Juiciness & $7.3 \pm 1.1$ & $7.5 \pm 0.8$ & NS \\
Taste & $7.8 \pm 1.2$ & $8.0 \pm 0.8$ & NS \\
Aroma & $7.9 \pm 1.0$ & $7.9 \pm 0.7$ & NS \\
Colour & $6.9 \pm 1.2$ & $6.6 \pm 1.0$ & NS \\
Overall acceptability & & & \\
INF muscle & $6.5 \pm 1.8$ & $7.6 \pm 0.7$ & $*$ \\
Cross-section appearance & $6.9 \pm 1.4$ & $7.6 \pm 1.0$ & $*$ \\
Tenderness & $6.5 \pm 1.5$ & $7.4 \pm 0.9$ & NS \\
Juiciness & $7.6 \pm 1.0$ & $8.0 \pm 0.9$ & NS \\
Taste & $7.8 \pm 1.3$ & $8.2 \pm 0.8$ & NS \\
Aroma & $7.7 \pm 1.2$ & $7.9 \pm 0.8$ & $*$ \\
Colour & $7.1 \pm 0.7$ & $7.7 \pm 1.3$ & \\
Overall acceptability & & &
\end{tabular}

Sensorial attributes ranked on a 9-point scale; higher numbers indicate higher quality meat.

** mean values in rows differ at $P<0.01$; * mean values in rows differ at $P<0.05$; NS: insignificant differences.

with greater connective tissue surface area and higher total collagen content. As Corbin et al. (2015) and Hunt et al. (2014) showed that there is a positive correlation between overall acceptability and other sensory attributes of beef cuts, such as flavour, juiciness and tenderness. Moreover, there are conflicting reports concerning the relationship between beef tenderness evaluated by consumers and WBSF values. Hunt et al. (2014) noted a low, but significant correlation $(r=-0.21, P<0.01)$ between tenderness and WBSF for LT and no correlation for gluteus medius $(r=-0.01)$. Van Wezemael et al. (2014) reported a low but significant $(P$ $<0.05)$ correlation between tenderness and WBSF for SEM muscle $(r=-0.23$ and -0.28 , for Belgian Blue and Norwegian Red cattle, respectively) and no correlation for INF muscle ( $r=-0.04$ and -0.12 , for Belgian Blue and Norwegian Red cattle, respectively).

\section{Conclusions}

Heifers showed a higher daily body gain and dressing percentage than the single-calf cows, although no differences were noted in carcass conformation or fatness. The higher dressing percentage of heifers may have resulted from their younger age and the same lower weight of gastrointestinal and reproductive tract, as well as lower internal fat deposition. The SEM and INF muscles from single-calf cows contained a lower amount of water-soluble collagen than those from heifers, which indicates that the collagen in singlecalf cows had a higher amount of intra- and intermolecular bonds than that in heifers. Although these differences did not negatively influence meat tenderness, they increased the WBSF of the connective seam in the ventral part of INF muscle. The meat obtained from the carcasses of single-calf cows showed comparable, or even better, sensory quality than from the young heifers. Because heifers and single-calf cows of Polish Holstein-Friesian $x$ Limousine crossbred produce meat with similar eating quality, it can be concluded that it is reasonable to slaughter heifers after their first calving instead of young heifers. 


\section{Acknowledgements}

This study was conducted within the Project no. WND-POIG.01.03.01-00-204/09 Optimizing of Beef Production in Poland according to the "From Fork to Farm" strategy co-financed by the European Regional Development Fund under the Innovative Economy Operational Program 2007 - 2013. Barbara Jankowska, Ewa Dąbrowska and Piotr Kalinowski are kindly acknowledged for their help in performing chemical analyses.

\section{References}

Acheson, R.J., Woerner, D.R. \& Tatum, J.D., 2014. Effects of USDA carcass maturity on sensory attributes of beef produced by grain-finished steers and heifers classified as less than 30 months old using dentition. J. Anim. Sci. 92, 1792-1799.

Agbeniga, B., Webb, E.C. \& O'Neill, H.A., 2013. Influence of Kosher (Shechita) and conventional slaughter techniques on shear force, drip and cooking loss of beef. S. Afr. J. Anim. Sci. 43 (Suppl. 1), S98-S102.

ASTM, 2011. ASTM F 2925-11 Standard specification for tenderness marketing claims associated with meat cuts derived from beef.

Blomfield, L.J. \& Farrar, F., 1964. Factors affecting the determination of hydroxyproline. Anal. Chem. 20, 950-954.

Bourdon, R.M. \& Brinks, J.S., 1987. Simulated efficiency of range beef production III. Culling strategies and nontraditional management systems. J. Anim. Sci. 65, 963-969.

Bureš, D. \& Bartoň, L., 2012. Growth performance, carcass traits and meat quality of bulls and heifers slaughtered at different ages. Czech J. Anim. Sci. 57, 34-43.

Cabaraux, J.F., Hornick, J.L., Dotreppe, O., Dufrasne, I., Clinquart, A. \& Istasse, L., 2004. Effects of the calving number on animal performance, carcass and meat composition in finishing Belgian Blue double-muscled culled females. Livest. Prod. Sci. 87, 161-169.

Corbin, C.H., O'Quinn, T.G., Garmyn, A.J., Legako, J.F., Hunt, M.R., Dinh, T.T.N., Rathmann, R.J., Brooks, J.C. \& Miller, M.F., 2015. Sensory evaluation of tender beef strip loin steaks of varying marbling levels and quality treatments. Meat Sci. 100, 24-31.

Council Regulation (EC) No 1099/2009 of 24 September 2009 on the protection of animals at the time of killing. Official J. Eur. Union L 303, 1-30.

Dąbrowska, E., Modzelewska-Kapituła, M., Kwiatkowska, A., Jankowska, B. \& Cierach, M., 2010. Effect of thermal processing in steam environment on texture, juiciness, and collagen solubility in been top blade muscle. Żywność, Nauka, Technol., Jakość 73, 209-218.

Du Plessis, I. \& Hoffman, L.C., 2007. Effect of slaughter age and breed on the carcass traits and meat quality of beef steers finished on natural pastures in the arid subtropics of South Africa. S. Afr. J. Anim. Sci. 37, 143-153.

Dubost, A., Micol, D., Picard, B., Lethias, C., Andueza, D., Bauchart, D. \& Listrat, A., 2013. Structural and biochemical characteristics of bovine intramuscular connective tissue and beef quality. Meat Sci. 95, 555-561.

Ferguson, D.M. \& Warner, R.D., 2008. Have we under-estimated the impact of pre-slaughter stress on meat quality in ruminants. Meat Sci. 80, 12-19.

Field, R.A., McCormick, R., Balasubramanian, V., Sanson, D., Wise, J., Hixon, D., Riley, M. \& Russell, W., 1996. Growth, carcass and tenderness characteristics of virgin, spayed and single-calf heifers. J. Anim. Sci. 74, 2178-2186.

Fiems, L.O., De Campeneere, S., Van Caelenbergh, W., De Boever, J.L. \& Vanacker, J.M., 2003. Carcass and meat quality in double-muscled Belgian Blue bulls and cows. Meat Sci. 63, 345-352.

Galli, I., Teira, G., Perlo, F., Bonato, P., Tisocco, O., Monje, A. \& Vittone, S., 2008. Animal performance and meat quality in cull cows with early weaned calves in Argentina. Meat Sci. 79, 521-528. 
Highfill, C.M., Esquivel-Font, O., Dikeman, M.E. \& Kropf, D.H., 2012. Tenderness profiles of ten muscles from F1 Bos indicus $x$ Bos taurus and Bos taurus cattle cooked as steaks and roasts. Meat Sci. 90, 881-886.

Hildrum, K.I., Rødbotten, R., Høy, M., Berg, J., Narum, B. \& Wold, J.P., 2009. Classification of different bovine muscles according to sensory characteristics and Warner Bratzler shear force. Meat Sci. 83, 302-307.

Hill, F., 1966. The solubility of intramuscular collagen in meat animals of various ages. J. Food Sci. 31, 161-166.

Hoving-Bolink, A.H., Hanekamp, W.J.A. \& Walstra, P., 1999. Effects of diet on carcass, meat and eating quality of once-bred Piemontese x Friesian heifers. Livest. Prod. Sci. 57, 267-272.

Hunt, M.R., Garmyn, A.J., O'Quinn, T.G., Corbin, C.H., Legako, J.F., Rathmann, R.J., Brooks, J.C. \& Miller, M.F., 2014. Consumer assessment of beef palatability from four beef muscles from USDA Choice and Select graded carcasses. Meat Sci. 98, 1-8.

INRA, 1993. Nutrition Standards Cattle, Sheep and Goats - nutritive value of feeds for ruminants. Study according to INRA. IZ, Kraków (in Polish).

Jama, N., Muchenje, V., Chimonyo, M., Strydom, P.E., Dzama, K. \& Raats, J.G., 2008. Cooking loss components of beef from Nguni, Bonsmara and Angus steers. Afr. J. Agr. Res. 3, 416-420.

Jeremiah, L.E., Dugan, M.E.R., Aalhus, J.L. \& Gibson, L.L., 2003a. Assessment of the chemical and cooking properties of the major beef muscles and muscle groups. Meat Sci. 65, 985-992.

Jeremiah, L.E., Dugan, M.E.R., Aalhus, J.L. \& Gibson, L.L., 2003b. Assessment of the relationship between chemical components and palatability of major beef muscles and muscle groups. Meat Sci. 65, 1013-1019.

Kamatara, K., Mpairwe, D., Christensen, M., Mutetikka, D. \& Madsen, J., 2013. Sensory characteristics and tenderness of meat from Ankole bulls: influence of crossbreeding and feeding system. S. Afr. J. Anim. Sci. 43 (Suppl. 1), S107-S110.

Kien, S., 2004. The classification of carcass of adult bovine animals in the EUROP. Institute of Meat and Fat in Warsaw and Poznań, Warsaw, Poland.

Lepetit, J., 2008. Collagen contribution to meat toughness: Theoretical aspects. Meat Sci. 80, 960-967.

Li, C.B., Zhou, G.H. \& Xu, X.L., 2010. Dynamical changes of beef intramuscular connective tissue and muscle fiber during heating and their effects on beef shear force. Food Bioprocess Technol. 3, 521-527.

Litwińczuk, Z., Borkowska, D., Litwińczuk, A. \& Asarabowska, A., 1991. Slaughter value, physico-chemical and sensory quality of lowland black and white and crossbred NCB $\times$ Limousine single-calf heifers meat. Rocz. Nauk Roln. B. 107, 169-177. (in Polish).

Lucero-Borja, J., Pouzo, L.B., delaTorre, M.S., Langman, L., Carduza, F., Corva, P.M., Santini, F.J. \& Pavana, E., 2014. Slaughter weight, sex and age effects on beef shear force and tenderness. Livest. Sci. 163, 140-149.

Modzelewska-Kapituła, M. \& Nogalski, Z., 2014. Effect of gender on collagen profile and tenderness of infraspinatus and semimembranosus muscles of Polish Holstein-Friesian $\times$ Limousine crossbred cattle. Livest. Sci. 167, 417-424.

Modzelewska-Kapituła, M., Dąbrowska, E., Jankowska, B., Kwiatkowska, A. \& Cierach, M., 2012. The effect of muscle, cooking method and final internal temperature on quality parameters of beef roast. Meat Sci. 91, 195-202.

Moloney, A.P., Mooney, M.T., Troy, D.J. \& Keane, M.G., 2011. Finishing cattle at pasture at 30 months of age or indoors at 25 months of age: Effects on selected carcass and meat quality characteristics. Livest. Sci. 141, 17-23.

Nogalski, Z. \& Kijak, Z., 2001. Fattening performance and slaughter value of the offspring of Black and White cows and Welsh Black bulls. Czech J. Anim. Sci. 46, 68-73. 
Okumura, T., Saito, K., Sowa, T., Sakuma, H., Ohhashi, F., Tameoka, N., Hirayama, M., Nakayama, S., Sato, S., Gogami, T., Akaida, M., Kobayashi, E., Konishi, K., Yamada, S. \& Kawamura, T., 2012. Changes in beef sensory traits as somatic-cell-cloned Japanese black steers increased in age from 20 to 30 months. Meat Sci. 90, 159-163.

Oury, M.P., Picard, B., Briand, M., Blanquet, J.P. \& Dumont, R., 2009. Interrelationships between meat quality traits, texture measurements and physicochemical characteristics of $m$. rectus abdominis from Charolais heifers. Meat Sci. 83, 293-301.

Patterson, D.C., Steen, R.W.J., Moore, C.A., Moss, B.W. \& Kilpatrick, D.J., 2004. Effects of primiparity and subsequent management on carcass composition and quality of continental beef heifers. Livest. Prod. Sci. 86, 19-34.

Polish Standard PN-ISO 4121, 1998. Sensory analysis, methodology and evaluation of food products (in Polish).

Purslow, P.P., 2005. Intramuscular connective tissue and its role in meat quality. Meat Sci. 70, 435-447.

Reich, G., 1970. Collagen. Methods, results and directions of the research. WNT, Warszawa (in Polish).

Reiling, B.A., Berger, L.L., Faulkner, D.B, McKeith, F.K., Nash, T.G. \& Ireland, F.A., 1996. Effects of prenatal androgenization, melengestrol acetate, and Synovex-H on feedlot performance, carcass, and sensory traits of once-calved heifers. J. Anim. Sci. 74, 2043-2051.

Schönfeldt, H.C. \& Strydom, P.E., 2011. Effect of age and cut on tenderness of South African beef. Meat Sci. 87, 206-218.

Schreurs, N.M., Garcia, F., Jurie, C., Agabriel, J., Micol, D., Bauchart, D., Listrat, A. \& Picard, B., 2008. Meta-analysis of the effect of animal maturity on muscle characteristics in different muscles, breeds, and sexes of cattle. J. Anim. Sci. 86, 2872-2887.

Špehar, M., Vincek, D. \& Žgur, S., 2008. Beef quality: Factors affecting tenderness and marbling. Stočarstvo 62, 463-478.

Tatum, J.D., 2011. Animal age, physiological maturity, and associated effects on beef tenderness. Cattlemen's Beef Board and National Cattlemen's Beef Association. http://www.beefresearch.org/CMDocs/BeefResearch/PE_White_\%20Papers/Animal_Age.pdf, accessed 15 October 2014.

Van Wezemael, L., De Smet, S., Ueland, Ø. \& Verbeke, W., 2014. Relationships between sensory evaluations of beef tenderness, shear force measurements and consumer characteristics. Meat Sci. 97, 310-315.

Waggoner, A.W., Dikeman, M.E., Brethod, J.R. \& Kemp, K.E., 1990. Performance, carcass, cartilage calcium, sensory and collagen traits of longissimus muscles of open versus 30-month-old heifers that produced one calf. J. Anim. Sci. 68, 2380-2386.

Walsh, H., Martins, S., O'Neill, E.E., Kerry, J.P., Kenny, T. \& Ward, P., 2010. The effects of different cooking regimes on the cook yield and tenderness of non-injected and injection enhanced forequarter beef muscles. Meat Sci. 84, 444-448.

Wroński, M., 1999. Fattening effectiveness, slaughter value and meat quality of heifers and primipares coming from the commercial crossbreeding of the Black-White cows with meat bulls. Dissertations and Monographs (in Polish).

Xiong, Y.L., Mullins, O.E., Stika, J.F., Chen, J., Blanchard, S.P. \& Moody, W.G., 2007. Tenderness and oxidative stability of post-mortem muscles from mature cows of various ages. Meat Sci. 77, 105-113.

Zembayashi, M., 2001. Effect of suckling on growth and quantitative and qualitative carcass traits of oncecalved heifers. Meat Sci. 58, 277-282. 